\title{
Cigarette smoking among school-going adolescents in Lithuania: Results from the 2005 Global Youth Tobacco Survey
}

\author{
Bradley Jamison ${ }^{1}$, Adamson S Muula², Seter Siziya*3, Sara Graham¹ and Emmanuel Rudatsikira4
}

\begin{abstract}
Background: The majority of people who suffer morbidity due to smoking may have initiated smoking during adolescent period. The aim of this study is to determine the prevalence and associated factors for cigarette smoking among school-going adolescents in Lithuania.

Findings: Data from the Global Youth Tobacco Survey (GYTS) 2005 were used to conduct this study. Data were analyzed using SUDAAN software 9.03. Comparisons for categorical variables were done using the Pearson's Chisquare test. The cut of point for statistical significance was set at $5 \%$ level. Logistic regression analyses were conducted to determine factors associated with the outcome. Unadjusted odds ratios (OR) and adjusted odds ratios (AOR) together with their 95\% confidence intervals $(\mathrm{Cl})$ are reported.

Of the 1822 respondents, $35.8 \%$ males and $27.1 \%$ females reported being current cigarette smokers $(p<0.001)$. Having friends who smoke cigarettes was associated with smoking after controlling for age, gender, parental smoking status, and perception of risks of smoking (AOR $=3.76 ; 95 \% \mathrm{Cl}[2.33,6.90]$ for some friends using tobacco; and $\mathrm{AOR}=17.18 ; 95 \% \mathrm{Cl}[10.46,28.21]$ for most or all friends using tobacco). Male gender and having one or both parents who smoke cigarettes were associated with smoking $(\mathrm{AOR}=1.31 ; 95 \% \mathrm{Cl}[1.03,1.66])$ and $\mathrm{AOR}=1.76 ; 95 \% \mathrm{Cl}$ $[1.37,2.27])$ respectively).

Conclusions: There is a high prevalence of cigarette smoking among Lithuanian adolescents. Male adolescents and adolescents who have friends or parents who smoke should be the main target for tobacco control in Lithuania.
\end{abstract}

\section{Background}

Tobacco use is a leading cause of adult mortality across the world. It is estimated that tobacco-attributable deaths are projected to rise from 5.4 million in 2005 to 8.3 million in 2030. By 2015, tobacco use is projected to cause $50 \%$ more deaths than AIDS $[1,2]$.

Much of the morbidity and mortality associated with tobacco use, such as cancers, chronic lower respiratory obstructive conditions and cardiovascular morbidity and mortality are experienced after several decades of smoking [1-4]. The majority of people who suffer morbidity later in life had initiated smoking as adolescents or young adults [5].

* Correspondence: ssiziya@yahoo.com

${ }^{3}$ Department of Community Medicine, School of Medicine, University of Zambia, Lusaka, Zambia

Full list of author information is available at the end of the article
Studies conducted in Lithuania include that of Garmiene et al [6] who reported a smoking prevalence of $1.2 \%$ among fifth grade adolescents of whom $6.5 \%$ girls and $23.0 \%$ boys had ever tried smoking. This report however was from one setting (Kaunas) and included only 369 school children. The results of the Lithuanian GYTS 2005 that have been published [7] were limited to the analysis of data for the age group 13 to 15 years; and only reported the prevalence of tobacco use. Factors associated with current smoking were not reported in this report. However, these factors have been reported elsewhere [8-10] but public health actions have to be at local, national and regional level. We thus aimed to determine the prevalence and associated factors for cigarette smoking among school-going adolescents in Lithuania.

(c) 2010 Siziya et al; licensee BioMed Central Ltd. This is an open access article distributed under the terms of the Creative Commons B. Wed Central Attribution License (http://creativecommons.org/licenses/by/2.0), which permits unrestricted use, distribution, and reproduction in any medium, provided the original work is properly cited. 


\section{Methods}

Our study involved secondary analysis of existing data from the Lithuania Global Youth Tobacco Survey (GYTS) conducted in 2005. A comprehensive description of the methods and procedures is presented elsewhere [7-9]. In brief, the Lithuanian GYTS conducted in 2005 was a cross sectional study, that was aimed to recruit schoolgoing adolescents of ages 13 to 15 years using a two-stage probability sampling technique. In the first stage, primary sampling units were schools which were selected with a probability proportional to their enrolment size. In the second step, a systematic sample of classes in the selected schools was obtained. All students in the selected classes, irrespective of their actual ages (even when outside the 13 to 15 year age group) were eligible to participate. The school and class response rates were $100 \%$. However, out of the total sample eligible for participation, $82.8 \%$ eventually participated, representing $17.2 \%$ of the eligible students who were either absent or refused to participate in the survey.

\section{Questionnaire and variables}

A questionnaire was used and included 'core GYTS' and other additional questions as has been described elsewhere regarding the GYTS methodology [7-9]. Responses to questions were close ended with multiple-choice style format. The questionnaire included questions among others on tobacco use, knowledge and attitudes regarding tobacco, and pro- and anti-tobacco media and advertising exposure.

\section{Statistical analysis}

For purposes of analysis, current cigarette smoking was defined as per GYTS convention which is having smoked a cigarette, even a single puff, within the last 30 days [7]. Using the socio-ecological model (SEM) of health behavior [11], we selected the variables to be analyzed. In brief the SEM recognizes that for a behavior such as adolescent smoking, various factors operating at the individual, interpersonal, organizational, structural level and policy levels interact. The questions and possible responses that were selected for analysis in this study are shown in Table 1.

Data were analyzed using SUDAAN software 9.03 (Research Triangle Institute, Research Triangle Park, North Carolina, United states of America). Comparisons for the categorical variables were statistically conducted using the Pearson's Chi-square test. The cut off point for statistical significance was set at the $5 \%$ level.

In order to estimate the associations between the explanatory variables and the outcome variable, bivariate logistic regression analyses were conducted, and obtained unadjusted odds ratios (OR) and their 95\% confidence intervals (CI); and finally, a multivariate logistic regres- sion model was run to determine independent predictors for the outcome, and the results are presented as adjusted odds ratios (AOR) and their 95\% CI.

\section{Ethical considerations}

These data were obtained on request from the Centers for Diseases Control and Prevention, Atlanta, Georgia. The study was approved by the Committee on Health Promotion of the Ministry of National Education and Religion [8]. Parents were informed of the study through a letter, and students gave verbal consent to participate in the survey. To preserve individual confidentiality, the questionnaire was self-completed anonymously by the student.

\section{Results}

\section{Characteristics of study participants}

A total of 1853 students participated in the survey. Of the 1822 (98.3\%) students who reported their sex, 948 $(52.0 \%)$ were female. The median age was $14\left(\mathrm{Q}_{1}=13, \mathrm{Q}_{3}\right.$ $=15)$ years.

\section{Prevalence of cigarette smoking}

Altogether, $35.8 \%$ males and $27.1 \%$ females reported being current cigarette smokers $(\mathrm{p}<0.001)$.

Table 2 indicates that participants were exposed to tobacco advertisements through TV (70.7\%), billboards $(100 \%)$, and newspapers or magazines (63.4\%). More than 1 in 2 respondents (54.1\%) reported having seen cigarette advertisements at sports events in the past 30 days.

Table 3 indicates that the vast majority $(92.0 \%)$ of the respondents felt that cigarette smoking is harmful. More than two-thirds (69.5\%) of the respondents thought that males who smoked cigarettes had more friends while $37.1 \%$ thought so for females. There were 1.74 times more respondents who thought that male smokers were attractive compared to those who thought so for female smokers ( $12.2 \%$ and $7.0 \%$, respectively).

Table 4 shows that age, parental and best friend smoking status were significantly associated with current cigarette smoking in bivariate analyses. These factors remained significantly associated with the outcome in a multivariate analysis. Having friends who smoke cigarettes was very strongly associated with tobacco use after controlling for age, gender, parental smoking status, and perception of hazards caused by smoking. For those respondents who had most or all friends who smoked cigarettes, we found a more than a seventeen-fold increase in the odds of smoking compared to those who had no smoking friends (AOR $=17.18 ; 95 \%[10.46,28.21]$ ). Those who had some friends who smoked were more than three times likely to smoke than those who had no smoking friends $(\mathrm{AOR}=3.76$; $95 \% \mathrm{CI}[2.33$; 95\% CI $[2.33,6.90])$. 
Table 1: Questions asked and options provided in the survey, and recoding for analysis.

\begin{tabular}{|c|c|c|}
\hline Question & Options provided & Re-coding for analysis \\
\hline $\begin{array}{l}\text { During the past } 30 \text { days (one month), on } \\
\text { how many days did you smoke cigarettes? }\end{array}$ & $\begin{array}{l}0 \text { day; } 1 \text { or } 2 \text { days; } 3 \text { to } 5 \text { days; } 6 \text { to } 9 \text { days; } \\
10 \text { to } 19 \text { days; } 20 \text { to } 29 \text { days; all } 30 \text { days }\end{array}$ & $\begin{array}{l}\text { Any number of days except } 0 \text { were coded } \\
\text { as current smoker }=\text { yes ( } 1 \text { ) }\end{array}$ \\
\hline $\begin{array}{l}\text { Do you think boys who smoke cigarettes } \\
\text { have more or less friends? }\end{array}$ & $\begin{array}{l}\text { More friends; Less friends; No difference } \\
\text { from non-smokers }\end{array}$ & $\begin{array}{l}\text { Re-coded as binary variable, less friends } \\
\text { and makes no difference combined and } \\
\text { recoded }=0 \text {; More friends recoded }=1\end{array}$ \\
\hline $\begin{array}{l}\text { Do you think girls who smoke cigarettes } \\
\text { have more or less friends? }\end{array}$ & $\begin{array}{l}\text { More friends; Less friends; No difference } \\
\text { from non-smokers }\end{array}$ & $\begin{array}{l}\text { Re-coded as binary variable, less friends } \\
\text { and makes no difference combined and } \\
\text { recoded }=0 \text {; More friends recoded }=1\end{array}$ \\
\hline $\begin{array}{l}\text { Do you think smoking cigarettes makes } \\
\text { girls look more or less attractive }\end{array}$ & $\begin{array}{l}\text { More attractive; Less attractive; Smoking } \\
\text { doesn't make a difference }\end{array}$ & $\begin{array}{l}\text { Less attractive and doesn't make a } \\
\text { difference recoded = 0; More attractive } \\
\text { coded }=1\end{array}$ \\
\hline $\begin{array}{l}\text { Do you think smoking cigarettes makes } \\
\text { boys look more or less attractive }\end{array}$ & $\begin{array}{l}\text { More attractive; Less attractive; Smoking } \\
\text { doesn't make a difference }\end{array}$ & $\begin{array}{l}\text { Less attractive and doesn't make a } \\
\text { difference recoded =0; More attractive } \\
\text { coded }=1\end{array}$ \\
\hline $\begin{array}{l}\text { Do you think cigarette smoking is harmful } \\
\text { to your health? }\end{array}$ & $\begin{array}{l}\text { Definitely not; Probably not; Probably yes; } \\
\text { Definitely yes }\end{array}$ & $\begin{array}{l}\text { Definitely yes or probably yes coded }=1 \text {; } \\
\text { Otherwise } 0\end{array}$ \\
\hline $\begin{array}{l}\text { Do any of your closest friends smoke } \\
\text { cigarettes? }\end{array}$ & $\begin{array}{l}\text { None of them; Some of them; Most of } \\
\text { them; all of them }\end{array}$ & $\begin{array}{l}\text { Indicator variables created, with one of the } \\
\text { categories as referent }\end{array}$ \\
\hline $\begin{array}{l}\text { During the past } 30 \text { days (one month), } \\
\text { when you watched sports events or other } \\
\text { programs on TV how often did you see } \\
\text { cigarette brand names? }\end{array}$ & I never watch TV; A lot; Sometimes; Never. & $\begin{array}{l}\text { Never and I never watch TV combined and } \\
\text { coded }=0 ; A \text { lot or sometimes coded }=1\end{array}$ \\
\hline $\begin{array}{l}\text { During the past } 30 \text { days (one month), how } \\
\text { many advertisements for cigarettes have } \\
\text { you seen on billboards? }\end{array}$ & A lot; A few; None & None $=0 ; \mathrm{A}$ lot or a few $=1$ \\
\hline $\begin{array}{l}\text { During the past } 30 \text { days (one month), how } \\
\text { many advertisements or promotions for } \\
\text { cigarettes have you seen in newspapers or } \\
\text { magazines? }\end{array}$ & A lot; A few; None & None $=0 ; \mathrm{A}$ lot or a few $=1$ \\
\hline $\begin{array}{l}\text { When you go to sports events, fairs, } \\
\text { concerts, community events, or other } \\
\text { events, how often do you see anti-smoking } \\
\text { information? }\end{array}$ & A lot; A few; None & None $=0 ; \mathrm{A}$ lot or a few $=1$ \\
\hline
\end{tabular}

Males were more likely to report cigarette smoking than females $(\mathrm{AOR}=1.31 ; 95 \% \mathrm{CI}[1.03,1.66]$.

\section{Discussion}

We found a prevalence of current cigarette smoking of $35.8 \%$ and $27.1 \%$ among Lithuanian school-going adolescent males and females respectively. Although there is male predominance, the smoking prevalence among females is much higher than the average prevalence of cigarette smoking among female youth in Europe [12] but similar to what has been reported in Cyprus [13]. Christophi et al [13] have reported smoking prevalence of $36 \%$ among boys and 23\% among girls in high schools in Cyprus. Among in-school adolescents in some European countries, Warren et al [7] have reported prevalence of current cigarette smoking of $8.5 \%$ in Albania (2004), $26.5 \%$ in Belarus (2004), $10.4 \%$ in Greece (2005), $32.9 \%$ in Latvia (2007) and 24.1\% in Croatia (2007).
The male predominance in cigarette smoking has been reported in Africa, India and Europe but is not universal [14]. A comprehensive report of global adolescent smoking patterns by Warren et al [7] has shown in general male predominance is high in Africa and Asia, while in the United States and parts of Europe, the gap between the sexes is limited. We do not know the reasons behind these patterns but we suggest that they may have to do with cultural acceptability of female smoking. If smoking among women is perceived in negative terms more than male smoking is in any particular society, we hypothesize that females in that society are less likely to smoke. The findings in the current study that about 2 in 3 adolescents reported that boys who smoke have more friends while only 1 in 3 thought that girls who smoke have more friends supports the assertion that male smokers are more accepted by society in Lithuania than female smokers. 
Table 2: Exposure to cigarette advertisements among adolescents in Lithuania.

\begin{tabular}{|c|c|c|c|}
\hline Characteristics & $\begin{array}{l}\text { Number } \\
\text { of participants }\end{array}$ & $\begin{array}{l}\% \\
\text { of total }\left[95 \% \mathrm{Cl}^{*}\right]\end{array}$ & p-value \\
\hline $\begin{array}{l}\text { See cigarette adverts when } \\
\text { watching TV }\end{array}$ & 1735 & $70.7[68.5,72.9]$ & 0.082 \\
\hline Males & 826 & $73.0[69.8,76.0]$ & \\
\hline Females & 909 & $68.7[65.5,71.7]$ & \\
\hline $\begin{array}{l}\text { Seen cigarette adverts on } \\
\text { billboards in past } 30 \text { days }\end{array}$ & 1428 & 100 & \\
\hline Males & 657 & 100 & \\
\hline Females & 771 & 100 & \\
\hline $\begin{array}{l}\text { Seen cigarette adverts in } \\
\text { newspapers or magazines in } \\
\text { past } 30 \text { days }\end{array}$ & 1808 & $63.4[61.2,65.7]$ & 0.017 \\
\hline Males & 862 & $60.4[57.1,63.7]$ & \\
\hline Females & 946 & $66.2[63.1,69.2]$ & \\
\hline $\begin{array}{l}\text { Seen cigarette adverts at } \\
\text { sports events in past } 30 \text { days }\end{array}$ & 1800 & $54.1[51.7,56.4]$ & 0.358 \\
\hline Males & 861 & $54.9[51.4,58.3]$ & \\
\hline Females & 939 & $53.3[50.0,56.4]$ & \\
\hline
\end{tabular}

$\mathrm{Cl}^{*}$ Confidence Interval

Table 3: Attitudes towards cigarette smoking distributed by gender in Lithuania.

\begin{tabular}{|c|c|c|c|}
\hline Characteristic & $\begin{array}{l}\text { Number } \\
\text { of participants }\end{array}$ & $\begin{array}{l}\% \\
\text { of total }\left[95 \% \mathrm{Cl}^{*}\right]\end{array}$ & p-value \\
\hline $\begin{array}{l}\text { Felt that boys who smoke } \\
\text { cigarette have more friends }\end{array}$ & 832 & $69.5[66.3,72.5]$ & 0.657 \\
\hline Males & 391 & $68.4[66.3,72.5]$ & \\
\hline Females & 441 & $70.3[66.0,74.6]$ & \\
\hline $\begin{array}{l}\text { Felt like girls who smoke } \\
\text { cigarettes have more friends }\end{array}$ & 921 & $37.1[34.0,40.3]$ & 0.618 \\
\hline Males & 467 & $37.8[33.5,42.4]$ & \\
\hline Females & 454 & $36.3[32.0,40.9]$ & \\
\hline $\begin{array}{l}\text { Felt that boys who smoke } \\
\text { cigarettes are attractive }\end{array}$ & 1180 & $12.2[10.4,14.2]$ & 0.001 \\
\hline Males & 518 & $16.1[13.1,19.7]$ & \\
\hline Females & 662 & $9.1[7.1,11.6]$ & \\
\hline $\begin{array}{l}\text { Felt that girls who smoke } \\
\text { cigarettes are attractive }\end{array}$ & 1426 & $7.0[5.8,8.5]$ & 0.001 \\
\hline Males & 646 & $10.3[8.2,13.0]$ & \\
\hline Females & 780 & $4.3[3.0,6.1]$ & \\
\hline $\begin{array}{l}\text { Felt that cigarettes smoking is } \\
\text { harmful to health }\end{array}$ & 1809 & $92.0[90.6,93.2]$ & $<0.001$ \\
\hline Males & 864 & $89.6[87.3,91.6]$ & \\
\hline Females & 945 & $94.1[92.3,95.5]$ & \\
\hline
\end{tabular}

$\mathrm{Cl}^{*}$ Confidence Interval 
Table 4: Factors associated with current cigarette smoking in Lithuania.

\begin{tabular}{|c|c|c|c|}
\hline Characteristic & $\begin{array}{l}\text { Cigarette smokers } \\
\% \text { (n) }\end{array}$ & $\mathrm{OR}^{*}\left[95 \% \mathrm{Cl}^{* *}\right]$ & $\mathrm{AOR}^{* * *}[95 \% \mathrm{Cl}]$ \\
\hline Age (years) & $31.3(533)$ & & \\
\hline$=<13$ & $18.8(109)$ & 1.00 & 1.00 \\
\hline 14 & $27.5(167)$ & $1.56[1.18,2.05]$ & $1.16[0.85,1.58]$ \\
\hline 15 & $44.1(203)$ & $3.35[2.53,4.42]$ & $2.22[1.61,3.06]$ \\
\hline$>=16$ & $60.3(54)$ & $6.04[3.78,9.64]$ & $4.06[2.37,6.96]$ \\
\hline \multicolumn{4}{|l|}{ Gender } \\
\hline Female & $27.1(237)$ & 1.00 & 1.00 \\
\hline Male & $35.8(284)$ & $1.54[1.25,1.89]$ & $1.31[1.03,1.66]$ \\
\hline \multicolumn{4}{|l|}{ Parental smoking status } \\
\hline None & $22.7(156)$ & 1.00 & 1.00 \\
\hline $\begin{array}{l}\text { One or both parents } \\
\text { smokers }\end{array}$ & $37.4(372)$ & $1.99[1.60,2.48]$ & $1.76[1.37,2.27]$ \\
\hline \multicolumn{4}{|l|}{ Best friends smoking status } \\
\hline None & $6.7(21)$ & 1.00 & 1.00 \\
\hline Some & $23.9(212)$ & $4.35[2.72,6.95]$ & $3.76[2.33,6.90]$ \\
\hline Most or all & $61.0(292)$ & $22.52[13.94,36.37]$ & $17.18[10.46,28.21]$ \\
\hline \multicolumn{4}{|l|}{$\begin{array}{l}\text { Perception that smoking is } \\
\text { harmful to health }\end{array}$} \\
\hline No & $35.9(45)$ & 1.00 & 1.00 \\
\hline Yes & $30.9(484)$ & $0.81[0.55,1.18]$ & $0.83[0.52,1.32]$ \\
\hline
\end{tabular}

We found that exposure to pro-tobacco advertisement exceeded half of the sample, and in some of the exposures approaching three-quarters. Data on adolescent smoking has shown that pro-teen advertisements are an important factor in influencing initiation and maintenance of adolescent smoking $[4,15]$. The findings that smoking in a parent, best friend and increasing age were positively associated with smoking have also been reported elsewhere [16-19].

This study has several inherent limitations. Firstly, the data were collected via a self-reported questionnaire. Like all questionnaires, the possibility of mis-reporting both intentional and unintentional threatens the validity and reliability of the findings. No biomarkers were assessed to confirm current cigarette smoking status. However, data from the United States using a similar questionnaire as the GYTS have reported high reliability among students in reporting personal health-compromising behaviors $[20,21]$. The extent as to whether similarly high reliability values could be obtained in settings outside of the United States is not known. Secondly, only students enrolled and available in schools during the administration of the questionnaire and completed it, were surveyed; leaving out $17.2 \%$ of adolescent students. To the extent that these students are not representative of all the adolescents in school, and of the overall adolescent population in the country (including out of school adolescents) our findings may not be generalized to the in-school adolescents, and to the adolescent population in Lithuania.

\section{Conclusions}

Our study has found that the prevalence of cigarette smoking among adolescent students was $35.8 \%$ for males and $27.1 \%$ for females. Being male and having friends or parents who smoke were associated with cigarette smoking. Male adolescents and adolescents who have friends or parents who smoke should be the main target for tobacco control guided by the WHO Framework Convention on Tobacco Control that Lithuania ratified in 2004.

Competing interests

The authors declare that they have no competing interests.

\section{Authors' contributions}

BJ participated in the interpretation of data and drafting of the manuscript; ASM participated in the interpretation of the results and led the manuscript drafting effort. SS participated in the interpretation of the results and the drafting of the manuscript. SG participated in the interpretation of data and draft- 
ing of the manuscript; and ER designed the data analysis plan, conducted the analysis and participated in the interpretation of the results. All authors read and approved the final manuscript.

\section{Acknowledgements}

We gratefully acknowledge the wonderful efforts by the Lithuanian 2005 GYTS research team in successfully completing the collection of data. To the students we say thank you for your participation, and we hope that the results of this study will be used to improve your health and that of the other adolescents in Lithuania.

\section{Author Details}

'Department of Global Health, School of Public Health, Loma Linda University, Loma Linda, California, USA, 2Department of Community Medicine and Public Health, College of Medicine, University of Malawi, Blantyre, Malawi, ${ }^{3}$ Department of Community Medicine, School of Medicine, University of Zambia, Lusaka, Zambia and ${ }^{4}$ Division of Epidemiology and Biostatistics, Graduate School of Public Health, San Diego State University, San Diego, California, USA

Received: 1 February 2010 Accepted: 7 May 2010

Published: 7 May 2010

\section{References}

1. Mathers CD, Loncar D: Projections of global mortality and burden of disease from 2002 to 2030. PLoS Med 2006, 3:e442.

2. Peto R, Lopez AD: Future worldwide health effects of current smoking patterns. In Critical Issues in Global Health Edited by: Koop CE, Pearson CE, Schwarz MR. San Francisco, CA: Jossey-Bass; 2001.

3. Ezzati M, Lopez AD: Estimates of global mortality attributable to smoking in 2000. Lancet 2003, 362:847-852.

4. Warren CD, Jones NR, Eriksen MP, Asma S, Global Tobacco Surveillance System (GTSS) collaborative group: Patterns of global tobacco use in young people and implications for future chronic disease burden in adults. Lancet 2006, 367:749-753.

5. Bourgkard E, Wild P, Massin N, Meyer JP, Otero Sierra C, Fontana JM, Benamghar L, Mur JM, Ravaud JF, Guillemin F, Chau N, Lorhandicap Group: Association of physical job demands, smoking and alcohol abuse with subsequent premature mortality: a 9-year follow-up population-based study. J Occup Health 2008, 50:31-40.

6. Garmiene A, Zemaitiene N, Zaborskis A: Family time, parental behaviour model and the initiation of smoking and alcohol use by ten-year-old children: an epidemiological study in Kaunas, Lithuania. BMC Public Health 2006, 6:287.

7. Warren CW, Jones NR, Peruga A, Chauvin J, Baptiste JP, Costa de Silva V, el Awa F, Tsouros A, Rahman K, Fishburn B, Bettcher DW, Asma S: Centers for Disease Control and Prevention (CDC). Global youth tobacco surveillance, 2000-2007. MMWR Surveill Summ 2008, 57:1-28.

8. Kyrlesi A, Soteriades ES, Warren CW, Kremastinou J, Papastergiou P, Jones NR, Hadjichristodoulou C: Tobacco use among students aged 13-15 years in Greece: the GYTS project. BMC Public Health 2007, 7:3.

9. Rudatsikira E, Muula AS, Siziya S, Mataya RH: Correlates of cigarette smoking among school-going adolescents in Thailand: findings from the Thai Global Youth Tobacco Survey 2005. Int Arch Med 2008, 1:8.

10. Stigler MH, Perry CL, Arora M, Reddy KS: Why are urban Indian 6th graders using more tobacco than 8th graders? Findings from Project MYTRI. Tob Control 2006, 15(Suppl 1):i54-60.

11. Naylor PJ, Macdonald HM, Reed KE, McKay HA: Action Schools! BC: a socioecological approach to modifying chronic disease risk factors in elementary school children. Prev Chronic Dis 2006, 3:A60.

12. Baska T, Warren CW, Baskova M, Jones NR: Prevalence of youth cigarette smoking and selected social factors in 25 European countries: findings from the Global Youth Tobacco Survey. Int J Public Health 2009, 54:439-445.

13. Christophi CA, Kolokotroni O, Alpert HR, Warren CW, Jones NR, Demokritou P, Connolly GN: Prevalence and social environment of cigarette smoking in Cyprus youth. BMC Public Health 2008, 8:190

14. Global Youth Tobacco Survey Collaborating Group: Differences in worldwide tobacco use by gender: findings from the Global Youth Tobacco Survey. J Sch Health 2003, 73:207-215.
15. Centers for Disease Control and Prevention (CDC): Youth exposure to alcohol advertising in magazines--United States, 2001-2005. MMWR Morb Mortal Wkly Rep 2007, 56:763-767.

16. Braun S, Mejia R, Ling PM, Pérez-Stable EJ: Tobacco industry targeting youth in Argentina. Tob Control 2008, 17:111-117.

17. Madan Kumar PD, Poorni S, Ramachandran S: Tobacco use among school children in Chennai city, India. Indian J Cancer 2006, 43:127-131.

18. Weiss JW, Cen S, Schuster DV, Unger JB, Johnson CA, Mouttapa M, Schreiner WS, Cruz TB: Longitudinal effects of pro-tobacco and antitobacco messages on adolescent smoking susceptibility. Nicotine Tob Res 2006, 8:455-465

19. Dirocco DN, Shadel WG: Gender differences in adolescents' responses to themes of relaxation in cigarette advertising: Relationship to intentions to smoke. Addict Behav 2007, 32:205-213.

20. Brener ND, Collins JL, Kann L, Warren CW, Williams BI: Reliability of the Youth Risk Behavior Survey Questionnaire. Am J Epidemiol 1995, 141:575-580.

21. Martin Gl, Newman IM: Assessing the validity of self-reported adolescent cigarette smoking. J Drug Educ 1983, 18:275-284.

doi: $10.1186 / 1756-0500-3-130$

Cite this article as: Jamison et al., Cigarette smoking among school-going adolescents in Lithuania: Results from the 2005 Global Youth Tobacco Survey BMC Research Notes 2010, 3:130

\section{Submit your next manuscript to BioMed Central and take full advantage of:}

- Convenient online submission

- Thorough peer review

- No space constraints or color figure charges

- Immediate publication on acceptance

- Inclusion in PubMed, CAS, Scopus and Google Scholar

- Research which is freely available for redistribution

Submit your manuscript at www.biomedcentral.com/submit
C BioMed Central 